\title{
NEEDS ASSESSMENTS OF MEDICAL STUDENTS IN OBSTETRICS AND GYNAECOLOGY
}

\author{
Madhulatha Alexander ${ }^{1}$, K. Sunanda ${ }^{2}$ \\ ${ }^{1}$ Assistant Professor, Department of Obstetrics and Gynaecology, Gandhi Medical College, Secunderabad. \\ ${ }^{2}$ Assistant Professor, Department of Obstetrics and Gynaecology, Gandhi Medical College, Secunderabad.
}

\begin{abstract}
BACKGROUND

In its Vision 2015 statement $^{1}$, the Government of India recognises Health for all as a national goal and expects medical training to produce competent "Physicians of First Contact" towards meeting this goal. The Medical Council of India aims to produce a clinician who understands and provides preventive, promotive, curative, palliative, and holistic care with compassion. In its endeavour to reach this goal, the MCI has emphasised the role of self-directed learning or encouragement of a learner-centric approach. A greater emphasis is placed on exposure to primary and secondary levels of care and to Competency-Based Learning (CBE).
\end{abstract}

\section{AIM}

In an attempt to crystallise this vision, the Obstetrics and Gynaecology Department at Gandhi Medical College, Secunderabad decided to give the students a questionnaire, which would address their needs regarding medical education in Obstetrics and Gynaecology and what innovations they would envisage to be part of the teaching learning program of the department.

\section{METHODOLOGY}

A prepared questionnaire was given to students in 3 classes and their opinion on various aspects of the teaching in Obstetrics and Gynaecology was sought. The data was collated and analysed by simple proportions.

\section{RESULTS AND CONCLUSIONS}

Students found the theory classes conducted by the faculty wanting. They wanted more interactive sessions and group discussions. Rural exposure was not considered important. Postings in labour room, operation theatre, and family planning were considered inadequate. The needs of the students must be kept in mind to have effective teaching learning strategies.

\section{KEYWORDS}

Teachers, Teacher Community, Peer Learning, Professional Development, Faculty Development.

HOW TO CITE THIS ARTICLE: Alexander M, Sunanda K. Needs assessments of medical students in obstetrics and gynaecology. J. Evolution Med. Dent. Sci. 2016;5(61):4248-4250, DOI: 10.14260/jemds/2016/969

\section{INTRODUCTION}

Vision 2015 is a document brought out by the MCI to develop systems, which would continuously assess the needs, aspirations, and enhance the quality and standards of medical education training in India. ${ }^{1}$ The aim was to standardise the quality of graduate medical education in the form of an Indian Medical Graduate - a skilled and motivated basic doctor. ${ }^{1}$ The current system of medical knowledge in India is knowledge based. It is now recognised to move this system to a Competency-Based System (CBE) to ensure a graduate is skilled, motivated, and ready to meet the health needs of the country. ${ }^{2}$ To ensure that the product of the system is a competent doctor, inputs are needed to deliver on this paradigm shift to CBE. ${ }^{2}$

The purpose of this study is to evaluate what medical students in a prestigious government medical college think of the current medical education system, what innovations they want, and the deficiencies in the system. The questionnaire highlighted a few points, which would make learning more relevant to the learner by suggesting teaching learning

Financial or Other, Competing Interest: None.

Submission 24-06-2016, Peer Review 18-07-2016,

Acceptance 23-07-2016, Published 29-07-2016.

Corresponding Author:

Dr. Madhulatha Alexander,

185, West Marredpally,

Road No. 6 ,

Secunderabad-500026.

E-mail: alexmadhu@gmail.com

DOI: $10.14260 /$ jemds/2016/969 methods, which were competency based and involved the students actually reaching out and touching the community. This study was carried out in the Department of Obstetrics and Gynaecology. The teaching in this department has been only through the medium of lectures and bedside clinics to date.

In a systematic review done by Steinert et $\mathrm{al}^{3}$ to improve teaching effectiveness, one of the key features of effective faculty development included the use of provision of feedback. Feedback from students is mandatory to improve teaching methods ${ }^{4}$. The input of the students for changing the system will be invaluable. Although, the students were questioned mainly with respect to Obstetrics and Gynaecology, this could be applicable to other subjects too. Some of these students will be medical teachers one day. In a study by Mann $\mathrm{KV}$ et $\mathrm{al}^{5}$ the students wanted a rotation in medical education. Students too want the quality of education to improve and want to have a say in it.

Hence, this study was undertaken. There is a need to build faculty capacity through faculty development programs. Currently, most faculty are not familiar with or do not have the required expertise to implement these reforms. ${ }^{2}$

AIM

1. To evaluate what medical students think of the current medical system with respect to Obstetrics and Gynaecology and to assess their needs. 
2. And to apply this input for future programs aimed at producing competent individuals.

\section{METHODOLOGY/MATERIALS AND METHODS}

Three classes of medical students were selected. The first class was the First Clinical Year students who were being exposed to the basics of Obstetrics and Gynaecology. The second class was the Final Year Students who were actually studying the subject and preparing for the final exams in this subject. The third was the Interns who had just finished their posting in the subject. A prepared questionnaire was given to them to fill. This questionnaire was analysed by simple proportions.

\section{RESULTS}

Nearly, all the students (98.2\%) wanted innovations in the teaching learning methods - in fact only $7(1.8 \%)$ of the students did not want any change (Table 2). When the students were asked to evaluate the quality of theory classes taken in all the three groups, the majority of students (59\%) responded average (Table 3 ). There was actually an increase in the percentage of students responding to poor - from $12 \%$ in the first clinical year to $18 \%$ in the intern group, which was found to be statistically significant. When the students were asked if they wanted interactive sessions and group discussions (Table 4), there was a steady increase in the responders who wanted them - reaching to $65 \%$ in the intern group. In India, since a vast majority of people are living in rural areas, the students were asked if they would like to have some practical clinical exposure in rural areas.

But, there was resistance in all groups and in the intern group only $19 \%$ wanting the rural posting with a whopping $81 \%$ not wanting it. In Table 6 , where the students were asked if they were satisfied with the current exposure to the posting in labour room, about half of the students in all groups felt it was inadequate. In Table 7 , when the students were asked if the operation theatre posting was satisfactory, there was a steady increase in the dissatisfaction of the posting peaking at $87 \%$ in the intern group. Regarding family planning posting (Table 8), $88 \%$ of the students felt that it was inadequate.

In the qualitative analysis, students wanted student friendly classes with innovative topics, which were relevant to the community and the nation. Many wanted the classes to be made more interesting. Another comment was that teaching should not be only to complete the syllabus, but that the students should feel interested enough to want to listen to the class. One of the students expressed that students expected more from us teachers.

\begin{tabular}{|c|c|c|c|}
\hline $\begin{array}{c}\text { Students } \\
\text { Distribution }\end{array}$ & $\begin{array}{c}\text { Males } \\
(\%)\end{array}$ & $\begin{array}{c}\text { Females } \\
(\%)\end{array}$ & $\begin{array}{c}\text { Total } \\
(\%)\end{array}$ \\
\hline $\begin{array}{c}\text { First Clinical } \\
\text { year }\end{array}$ & $58(14.6)$ & $78(19.7)$ & $\begin{array}{c}136 \\
(34.4)\end{array}$ \\
\hline Final year & $64(16.3)$ & $84(21.3)$ & $\begin{array}{c}148 \\
(37.5)\end{array}$ \\
\hline Interns & $55(13.9)$ & $56(14.2)$ & $\begin{array}{c}111 \\
(28.1)\end{array}$ \\
\hline Total & $\begin{array}{c}\mathbf{1 7 7} \\
(\mathbf{4 4 . 8})\end{array}$ & $\begin{array}{c}\mathbf{2 1 8} \\
\mathbf{( 5 5 . 2 )}\end{array}$ & $\begin{array}{c}\mathbf{3 9 5} \\
(\mathbf{1 0 0})\end{array}$ \\
\hline Table 1: Distribution of Students According to Their \\
Year of Study \\
\hline
\end{tabular}

\begin{tabular}{|c|c|}
\hline \multicolumn{2}{|c|}{ Innovations Desired (\%) } \\
\hline Yes & $388(98.2)$ \\
\hline No & $7(1.8)$ \\
\hline Total & $\mathbf{3 9 5}(100)$ \\
\hline Table 2: Distribution According to Innovations Desired \\
\hline
\end{tabular}

\begin{tabular}{|c|c|c|c|c|}
\hline Quality & $\begin{array}{c}\text { First } \\
\text { Years } \\
(\%)\end{array}$ & $\begin{array}{c}\text { Final } \\
\text { Years } \\
(\%)\end{array}$ & $\begin{array}{c}\text { Interns } \\
(\%)\end{array}$ & $\begin{array}{c}\text { Total } \\
(\%)\end{array}$ \\
\hline Good & $28(21)$ & $35(24)$ & $16(14)$ & $79(20)$ \\
\hline Average & $91(67)$ & $87(58)$ & $55(50)$ & $\begin{array}{c}233 \\
(59)\end{array}$ \\
\hline Poor & $17(12)$ & $26(26)$ & $40(36)$ & $83(21)$ \\
\hline Total & $\mathbf{1 3 6}$ & $\mathbf{1 4 8}$ & $\mathbf{1 1 1}$ & $\mathbf{3 9 5}$ \\
& $(\mathbf{1 0 0 )}$ & $(\mathbf{1 0 0})$ & $(\mathbf{1 0 0})$ & $(\mathbf{1 0 0})$ \\
\hline \multicolumn{5}{|c|}{ Table 3: Quality of Theory Classes } \\
\hline
\end{tabular}

\begin{tabular}{|c|c|c|c|}
\hline Year of Students & Yes (\%) & No (\%) & Total (\%) \\
\hline First Clinical & $65(48)$ & $71(52)$ & $136(100)$ \\
\hline Final & $92(62)$ & $56(56)$ & $148(100)$ \\
\hline Interns & $72(65)$ & $39(35)$ & $111(100)$ \\
\hline Total & $\mathbf{2 2 9}(58)$ & $166(42)$ & $395(100)$ \\
\hline Table 4: Want Interactive Sessions, Seminars, \\
Group Discussions \\
\hline
\end{tabular}

\begin{tabular}{|c|c|c|c|}
\hline Year of Students & Yes (\%) & No (\%) & Total (\%) \\
\hline First Clinical & $21(15)$ & $115(85)$ & $136(100)$ \\
\hline Final & $32(22)$ & $116(78)$ & $148(100)$ \\
\hline Interns & $21(18)$ & $90(82)$ & $111(100)$ \\
\hline Total & $\mathbf{7 4 ( 1 8 )}$ & $\mathbf{3 2 1}(\mathbf{8 2})$ & $\mathbf{3 9 5}(\mathbf{1 0 0 )}$ \\
\hline Table 5: Is there a Need for Rural Visits to See How \\
Deliveries are Conducted in PHCs \\
\hline
\end{tabular}

\begin{tabular}{|c|c|c|c|}
\hline Year of Students & Yes (\%) & No (\%) & Total (\%) \\
\hline First Clinical & $62(46)$ & $74(54)$ & $136(100)$ \\
\hline Final & $76(51)$ & $72(49)$ & $148(100)$ \\
\hline Interns & $55(50)$ & $56(50)$ & $111(100)$ \\
\hline Total & 193 (48.9) & $202(51.1)$ & $395(100)$ \\
\hline Table 6: Need for More Practical Exposure in the \\
Labour Room \\
\hline
\end{tabular}

\begin{tabular}{|c|c|c|c|}
\hline $\begin{array}{c}\text { Year of } \\
\text { Students }\end{array}$ & Yes (\%) & No (\%) & Total (\%) \\
\hline First Clinical & $30(22)$ & $106(78)$ & $136(100)$ \\
\hline Final & $38(26)$ & $110(74)$ & $148(100)$ \\
\hline Interns & $14(13)$ & $97(87)$ & $111(100)$ \\
\hline Total & $\mathbf{8 2}(20.8)$ & $313(79.2)$ & $\mathbf{3 9 5}(100)$ \\
\hline Table 7: Is the Operation Theatre Posting Adequate? \\
\hline
\end{tabular}

\begin{tabular}{|c|c|c|c|}
\hline Year of Students & Yes (\%) & No (\%) & Total (\%) \\
\hline First Clinical & $12(9)$ & $124(91)$ & $136(100)$ \\
\hline Final & $24(16)$ & $124(84)$ & $148(100)$ \\
\hline Interns & $11(9)$ & $100(91)$ & $111(100)$ \\
\hline Total & $47(11.9)$ & $\mathbf{3 4 8}(88.1)$ & $395(100)$ \\
\hline Table 8: Is Exposure to Family Planning Practices \\
Adequate?
\end{tabular}

\section{DISCUSSION}

This study assessed the needs of medical students in Obstetrics and Gynaecology by taking their feedback. In a study done by Dragan Ilic et al ${ }^{4}$ students too rated feedback as a top attribute of a good educator. Feedback provides a two-way communication and provides a timely communication both positive and negative. ${ }^{4}$ Almost, all the students wanted innovations in the method of teaching. The 
quality and quantity of theory classes, which form the backbone of medical classes in India does not seem to impress our young students. Although, they were asked to evaluate the theory classes as good, average, and poor, and this is a subjective analysis, the students felt a deficiency in the class. There is a need to have more interactive sessions and group discussions in our system of medical education. The students do not want to have more rural exposure, although there is an urgent need to have more medical services in rural areas. Medical needs have to cater to all divisions of society. Compassion is lacking in the young students. Regarding labour room posting, operation theatre posting, and family planning where the emphasis is practical training, the students found it was inadequate. Maybe more individual care should be taken by educators by teaching them in smaller groups. Mentors could focus and encourage their studies in these areas.

Most of the newer learning modules are student centered and the teachers are merely facilitators in the student's quest for knowledge. These modules tend to make students lifelong learners. The community-based teaching modules have met with great success both in and out of India. They only need a lot of initial planning - dialoguing with the community and carving our niches in the rigid MCI curriculum, so that the students learn by doing things in the community. Once in place, both teaching and learning becomes a pleasure both for the learner and the facilitator. In a study done by Marcos Roos et $\mathrm{al}^{6}$, even the educators wanted to work to improve their academic teaching performance. Accurate self-assessment of educators is an essential part of improvement of teaching and this can be enhanced by feedback as seen in studies by Colthart I et al ${ }^{7}$.

\section{CONCLUSION}

This study aims to give an insight into what the student wants with respect to the teaching learning methods. In our study, it is easy to see that the present methods of teaching are found wanting and changes have to be incorporated to make the learning experience more acceptable to the present generation. Theory classes should improve and should be more interactive.
Medical education in India needs a paradigm shift. The needs of the students have to be taken into account to make this change. The curriculum needs to be revamped to make it relevant to the needs of our country. Results derived from studies such as this will help the medical education unit members to modify/emphasise/strengthen existing strategies, so that the ultimate challenge of improving the learners' knowledge, skills, and professional performance is met. 8

\section{REFERENCES}

1. Medical Council of India. Vision 2015-National meet on implementation of reforms in undergraduate and postgraduate medical education. 2011. http://www.mciindia.org/tools/announcement/MCI_b ooklet.pdf.

2. Chacko TV. Improving quality of medical education in India: the need to value and recognise academic scholarship. J Pharmacol Pharmacother 2013;4(3):1713.

3. Steinert $\mathrm{Y}$, Mann $\mathrm{K}$, Centeno A, et al. A systematic review of faculty development initiatives designed to improve teaching effectiveness in medical education: BEME guide no 8. Medical Teach 2006;28(6):497-526.

4. llic D, Harding J, Allan C, et al. What are the attributes of a good health educator? International Journal of Medical Education 2016;7:206-11.

5. Mann KV, Sutton E, Frank B. Twelve tips for preparing residents as teachers. Med Teach 2007;29(4):301-6.

6. Roos M, Kadmon M, Kirschfink M, et al. Developing medical educators-a mixed method evaluation of a teaching education program. Medical Education Online 2014;19(1):23868. doi:10.3402/meo.v19.23868.

7. Colthart I, Bagnall G, Evans A, et al. The effectiveness of self-assessment on the identification of learner needs, learner activity, and impact on clinical practice. BEME Guide no 10. Med Teach 2008;30(2):124-45.

8. Shrivastava SR, Shrivastava PS, Ramasamy J. Effective feedback: an indispensable tool for improvement in quality of medical education. Journal of Pedagogic Development 2014;4(1):12-20. 